\title{
Tradisi Pecotan dalam Perayaan Walimah Al-'Urs (Studi Analisis 'Urf di Desa Bandaran Kecamatan Tlanakan Kabupaten Pamekasan)
}

\author{
Novi Kartika Sari \\ Kudrat Abdillah \\ (Fakultas Syariah Institut Agama Islam Negeri Madura Pamekasan, \\ kudrat.abdillah@iainmadura.ac.id)
}

\begin{abstract}
Abstrak:
Tradisi pecotan dalam acara Walimah al-'urs mewajibkan para tamu untuk berdonasi uang dan merupakan syarat yang harus dipenuhi saat menghadiri undangan walimah. Pengembangan tradisi pecotan dalam perayaan walimahul 'urs di Desa Bandaran masih dilakukan oleh masyarakat karena tradisi ini memiliki sifat yang lestari. Tradisi ini jarang dilakukan. Namun makna tradisi pecotan dalam perayaan Walimah al-'urs tetap diwujudkan yaitu memberikan sumbangan selain biaya acara. (the pecotan tradition in the Walimah al-'urs event requires guests to donate money and is a condition that must be met when attending a walimah invitation. The development of the pecotan tradition in the Walimah al-'urs celebration in Bandaran Village is still carried out by the community because this tradition has a sustainable nature. This tradition is rarely carried out. However, the meaning of the pecotan tradition in the Walimah al-'urs celebration is still realized, namely giving donations other than the cost of the event.)
\end{abstract}

\section{Kata Kunci: \\ Tradisi Pecotan, Walimah al-'Urs, 'Urf.}

\section{Pendahuluan}

Walimah al-'urs dalam Islam dapat diselenggarakan sesuai dengan kemampuan seseorang yang melaksanakan perkawinan. 
Pelaksanaan Walimah al-'urs dianjurkan dengan sederhana agar tidak ada pemborosan, kemubaziran dengan disertai sifat sombong dan membanggakan diri. ${ }^{1}$ Penyelenggaraan Walimah al-'urs di masyarakat seringkali memaksakan diri untuk kemegahan ataupun kemewahannya bahkan untuk memenuhi keinginannya sampai berhutang kepada orang lain.

Walimah al-'urs diadakan ketika acara akad nikah berlangsung atau sesudahnya. Walimah al-'urs dapat juga diadakan menurut adat dan kebiasaan yang berlaku dalam masyarakat. Di Desa Bandaran Kecamatan Tlanakan Kabupaten Pamekasan mempunyai keunikan yang berbeda dalam mengundang masyarakat untuk menghadiri acara Walimah al-'urs, yang dikenal dengan tradisi pecotan. Tradisi ini bisa dikategorikan seperti adat, kebiasaan dan sebagainya yang turuntemurun dari nenek moyang, atau segala sesuatu yang diwariskan oleh masa lalu ke masa sekarang. Tradisi tersebut hingga saat ini masih diterima, diikuti bahkan dipertahankan oleh kelompok masyarakat tertentu. $^{2}$

Pecotan dalam Kamus Besar Bahasa Indonesia merupakan undangan yang disertai rokok agar pihak yang diundang hadir dengan membawa sejumlah uang. ${ }^{3}$ Mengundang dalam tradisi pecotan ini tidak hanya datang, bertemu dan menyampaikan undangan tetapi juga memberikan sesuatu barang sebagai simbolisasi undangan. Undangan pecotan ini berwujud sebungkus rokok yang diselipkan undangan kecil di bagian belakang bungkus rokok tentang perihal acara.

Masyarakat yang menerima undangan ini akan hadir pada acara dengan memberikan amplop yang berisi uang dengan jumlah minimal Rp. 50.000, berbeda dengan menerima undangan kertas biasa yang tidak ditentukan besar jumlahnya. Apabila tamu undangan pecotan tidak dapat menghadiri atau memberikan sumbangan sesuai ketentuan masyarakat, maka akan timbul rasa malu karena masyarakat lebih mempertimbangkan atau memikirkan penilaian orang lain terhadap dirinya. ${ }^{4}$

1Tihami dan Sahrani, Fiqh Munakahat: Kajian Fiqh Nikah Lengkap, 137.

2M. F. Zenrif, Realitas Keluarga Muslim: Antara Mitos dan Doktrin Agama, (Malang: UINMalang Press, 2008), 21.

3Pecotan di Kamus Besar Bahasa Indonesua (KBBI), diakses dari https://lektur.id/artipecotan/, pada tanggal 08 Agustus 2020.

4Toyati, Masyarakat Desa Bandaran, Wawancara Langsung, (Bandaran, 28 Juli 2020). 
Perayaan acara walimahul 'urs saat ini seolah-olah mengharapkan bantuan finansial berupa hadiah dan amplop dari para tamu yang hadir. Seorang yang menghadiri Walimah al-'urs tanpa membawa amplop berisi uang dianggap kurang sopan. Hal itulah yang sampai saat ini berlaku dalam masyarakat. Tetapi, ini merupakan suatu pergeseran dari tujuan digelarnya Walimah al-'urs yang sebenarnya. ${ }^{5}$

Undangan pecotan ini bertujuan untuk mendapatkan sumbangan uang yang jumlahnya lebih besar sebagai tambahan biaya dalam pesta perkawinan. Sumbangan dalam tradisi pecotan harus dikembalikan sehingga shahibul hajah mencatat tamu undangan yang hadir dan menuliskan jumlah uang sumbangannya. Catatan ini akan menjadi pedoman bagi shahibul hajah untuk mengembalikan sumbangan yang diterimanya. ${ }^{6}$ Apabila tamu undangan tidak dapat menghadiri acara dan tidak menitipkan uang sumbangannya kepada orang lain atau ada kekurangan dalam memberikan uang sumbangan, maka shahibul hajah akan meminta kekurangan tersebut dengan cara menegurnya setelah pelaksanaan acara. ${ }^{7}$

Tradisi pecotan dalam Walimah al-'urs ini merupakan aturan yang tidak tertulis, namun bersifat mengikat sehingga masyarakat memahami bahwa sesuatu yang sudah mentradisi di daerahnya itu, seperti menjadi syarat yang harus dipenuhi. Hal ini terbukti dari para tamu undangan dalam acara Walimah al-'urs harus memberikan sumbangan berupa uang dan ini menjadi salah satu syarat yang harus dipenuhi ketika menghadiri undangan tersebut.

Proses pelaksanaan tradisi pecotan dalam Walimah al-'urs saat ini telah mengalami perubahan seiring perkembangan zaman, karena sumbangan yang timbul dalam tradisi pecotan harus dikembalikan. Sumbangan ini seharusnya diberikan dengan rasa ikhlas untuk membantu meringankan beban shahibul hajah dalam membiayai pesta perkawinannya. Dalam tradisi pecotan sumbangan yang diberikan jumlahnya lebih besar karena dalam undangan pecotan ini ada batasan sumbangan yang harus dipenuhi. Tradisi pecotan di Desa Bandaran

5Sarwat, Ensiklopedia Fikih Indonesia 8: Pernikahan, 146.

${ }^{6}$ Muslimah, Masyarakat Desa Bandaran, Wawancara Langsung, (Bandaran, 05 Agustus 2020).

7Hairus Saleh, Masyarakat Desa Bandaran, Wawancara Langsung, (Bandaran, 05 Agustus 2020). 
saat ini mulai jarang dilaksanakan oleh sebagian masyarakat, tetapi ada pula yang tetap mempertahankan dan melaksanakan tradisi pecotan ini.

Tulisan ini terfokus pada dua pertanyaan, yaitu Bagaimana perkembangan tradisi pecotan dalam perayaan Walimah al-'urs di Desa Bandaran Kecamatan Tlanakan Kabupaten Pamekasan? Bagaimana tradisi pecotan dalam perayaan Walimah al-'urs di Desa Bandaran Kecamatan Tlanakan Kabupaten Pamekasan perspektif 'urf? Tulisan ini menggunakan jenis tulisan hukum empiris kualitatif. Pendekatan yang digunakan dalam tulisan ini adalah studi kasus (case study). Pendekatan studi kasus ini merupakan pendekatan yang digunakan untuk memahami suatu kejadian atau permasalahan dengan mengumpulkan berbagai macam sumber informasi untuk mendapatkan sebuah solusi dalam menyelesaikan permasalahan tersebut. 8

\section{Definisi Walimah al-'Urs dan Hukumnya}

Tradisi berasal dari bahasa latin, yaitu tradition yang artinya diteruskan atau suatu kebiasaan. Tradisi adalah sesuatu yang telah dilakukan sejak lama dan menjadi bagian dari kehidupan suatu kelompok masyarakat. ${ }^{9}$ Tradisi merupakan sinonim dari kata budaya yang keduanya sama-sama merupakan hasil karya masyarakat, keduanya saling mempengaruhi. Kedua kata ini bermakna hukum tak tertulis yang menjadi patokan norma dalam masyarakat yang dianggap baik dan benar. ${ }^{10}$

Istilah tradisi sering digunakan dan dijumpai dalam berbagai literatur. Dalam khazanah Indonesia, tradisi berarti segala sesuatu seperti adat, kebiasaan, ajaran dan sebagainya yang turun temurun dari nenek moyang atau segala sesuatu yang ditransmisikan, diwariskan dari masa lalu ke masa sekarang. ${ }^{11}$ Dalam ajaran Islam tradisi atau budaya bisa disebut al-'urf (kebiasaan-kebiasaan yang dipraktikan oleh sekelompok masyarakat), namun yang dianjurkan

8Jonaedi Efendi dan Johnny Ibrahim, Metode Tulisan Hukum Normatif dan Empiris, (Depok: Prenadamedia Group, 2018), 149.

${ }^{9}$ Anton, "Ungkapan Tradisional Dalam Upacara Adat Perkawinan Masyarakat Bajo di Pulau Balu Kabupaten Munabarat", Humanika, Vol 3, No. 15, (Desember, 2015), 3.

${ }^{10}$ Bashori Alwi, "Tradisi Pecotan dalam Pandangan Ilmu Sosiologi di Paiton Probolinggo", Maqashid Jurnal Hukum Islam, Vol. 2, No. 2, (2020), 34.

11Zenrif, Realitas Keluarga Muslim, 21. 
kebiasaan atau adat istiadat yang diperbolehkan dalam Islam adalah kebiasaan yang baik sedangkan yang buruk hendaknya dijauhkan dari kebiasaan masyarakat. ${ }^{12}$

Pecotan berasal dari bahasa Madura, yaitu pecot (cambuk). Kata pecotan ini digunakan sebagai simbolisasi dari sebuah keharusan bagi seseorang untuk hadir pada suatu acara dengan memberikan uang sumbangan setelah menerima undangan tertulis yang disertakan barang. ${ }^{13}$ Sedangkan kata pecotan dalam Kamus Besar Bahasa Indonesia merupakan undangan yang disertai rokok agar pihak yang diundang hadir dengan membawa sejumlah uang. ${ }^{14}$

Undangan pecotan ini bertujuan untuk mendapatkan sumbangan uang yang jumlahnya lebih besar sebagai tambahan biaya dalam pesta perkawinan. Sumbangan dalam tradisi pecotan harus dikembalikan seperti layaknya hutang piutang sehingga shahibul hajah mencatat tamu undangan yang hadir dan menuliskan jumlah uang sumbangannya. Catatan ini akan menjadi pedoman bagi shahibul hajah untuk mengembalikan sumbangan yang diterimanya.

Walimah al-'urs terdiri dari dua suku kata al-walimah dan al-'urs. al-walimah adalah al-jam'u (berkumpul), walimah disebut juga dengan tha'amu al-'urs (makanan dipersiapkan untuk acara berkumpul) dan 'urs memiliki makna al-jifaf wa al-tazwiz (nikah). ${ }^{15}$ Jadi, Walimah al-'urs adalah makanan yang disediakan khusus dalam acara pesta perkawinan atau sebagai makanan untuk para tamu undangan. ${ }^{16}$

Ibnu Atsir dalam Kitabnya Al-Nihayah (Juz V/226), mengemukakan bahwa Walimah al-'urs adalah:

Makanan yang dibuat untuk pesta perkawinan.

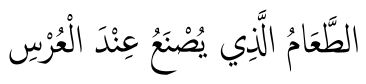

Walimah al-'urs dapat digelar ketika berlangsungnya acara akad nikah atau sesudahnya. Walimah al-'urs dapat juga diadakan menurut adat dan kebiasaan yang berlaku dalam masyarakat. ${ }^{17}$ Hukum

\footnotetext{
12Muyassarah, Nilai Budaya Walimah Perkawinan (Walimatul 'Urs) dalam Pemberdayaan Ekonomi Masyarakat, Vol. 10, No. 2, (Desember 2016), 546.

${ }^{13}$ Alwi, "Tradisi Pecotan dalam Pandangan Ilmu Sosiologi di Paiton Probolinggo", 36. ${ }_{14}$ Pecotan di Kamus Besar Bahasa Indonesua (KBBI), diakses dari https://lektur.id/arti-pecotan/, pada tanggal 08 Agustus 2020.

15Dahlan, Fikih Munakahat, 80-81.

16Sarwat, Ensiklopedia Fikih Indonesia 8: Pernikahan, 141.

17Tihami dan Sahrani, Fiqh Munakahat: Kajian Fiqh Nikah Lengkap, 131-132.
} 
mengadakan Walimah al-'urs adalah sunnah menurut kesepakatan para ahli ilmu. Sebagian dari mereka berpendapat bahwa hukumnya adalah wajib karena adanya perintah Rasulullah SAW untuk menyelenggarakannya dan karena kewajiban untuk menghadirinya. Menghadiri undangan merupakan suatu yang diperintahkan Rasulullah saw, karena dapat menunjukkan bentuk perhatian dan kepedulian serta mendatangkan kebahagiaan bagi shahibul hajah. Hal ini sesuai dengan hadits Nabi Muhammad saw. sebagai berikut:

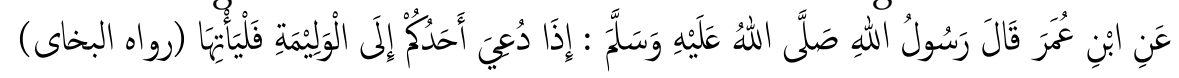

Dari Ibnu Umar, Rasulullah saw bersabda: "Jika salah satu di antra kalian diundang walimah maka datangilah. (HR. Bukhari). ${ }^{18}$

Untuk memeriahkan dan menggembirakan orang yang mengundang maka orang yang diundang Walimah al-'urs wajib menghadirinya. Adapun wajibnya menghadiri undangan Walimah al'urs, apabila: tidak ada udzur Syar'i, dalam Walimah al-'urs tidak diselenggarakan perbuatan munkar, dan tidak membedakan kaya dan miskin.

Dasar hukum wajibnya menghadiri undangan walimah adalah hadits Nabi saw, sebagai berikut:

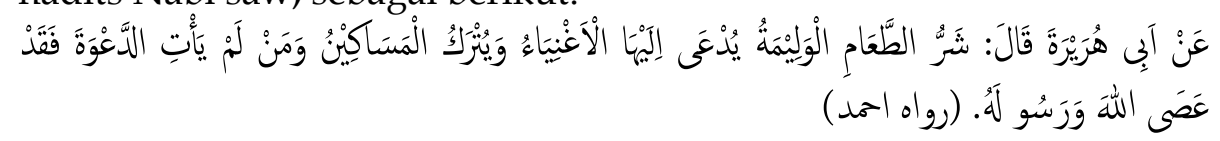

Dari Abu Hurairah r.a dia berkata: Seburuk-buruk makanan ialah makanan walimah yang di dalamnya hanya diundang orang-orang kaya tanpa orang-orang miskin, dan barangsiapa yang tidak menghadiri undangan maka ia telah bermaksiat kepada Allah dan Rasul-Nya. (HR. Ahmad). ${ }^{19}$

Sebagian ulama berpendapat bahwa hukum menghadiri undangan adalah wajib kifayah. Namun, ada juga ulama yang mengatakan sunnah, akan tetapi pendapat pertamalah yang lebih jelas.

\section{Eksistensi Tradisi Pecotan}

Walimah al-'urs, yaitu peresmian perkawinan dengan menghidangkan makanan untuk para tamu undangan. Hal ini bertujuan untuk memberitahu atau menginformasikan pada khalayak

18Muhammad bin Ismail Al-Bukhari, Shahih Bukhari, Kitab ke-47: Nikah, Bab 2711: Wajib Menghadiri Undangan Walimah, Hadits Nomor 4775.

${ }^{19}$ Ahmad bin Hanbal, Musnad Ahmad, Kitab ke-6, Bab 30, Hadits Nomor 6978. 
ramai bahwa kedua mempelai telah resmi menjadi pasangan suami istri. Pelaksanaan Walimah al-'urs ini tidak terlepas dari tradisi yang diwariskan nenek moyang dari zaman dahulu hingga sekarang. Salah satu tradisi yang sering dilakukan ketika melaksanakan Walimah al-'urs , yaitu tradisi pecotan. Tradisi pecotan telah menjadi tradisi yang terus dilakukan oleh masyarakat Desa Bandaran. Tradisi pecotan dalam perayaan Walimah al-'urs ini tumbuh dan berkembang di masyarakat itu sendiri.

Perkembangan zaman menjadi salah satu alasan perubahan dapat terjadi. Bagi masyarakat Desa Bandaran tradisi yang dilakukan pada perayaan Walimah al-'urs sudah menjadi kebiasaan yang turuntemurun. Namun, seiring berjalannya waktu, perubahan mulai mempengaruhi proses pelaksanaan tradisi pecotan dalam Walimah al'urs. Perubahan ini menjadi bukti adanya penyesuaian dari masyarakat terhadap perkembangan zaman.

Tradisi pecotan merupakan undangan khusus yang ditujukan kepada laki-laki untuk menghadiri pesta perkawinan. Undangan tersebut dibagikan dengan rokok sebagai simbolisasi undangan yang diselipkan kertas kecil tentang pelaksanaan acara. Penggunaan rokok sebagai simbolisasi undangan pecotan di Desa Bandaran karena rokok mengandung nilai ekonomis serta masyarakat akan lebih dihargai daripada hanya diberikan selembar kertas undangan saja. Apabila hanya diberikan kertas undangan saja masyarakat yang diundang terkadang ada yang tidak menghadiri pesta perkawinan tersebut.

Masyarakat yang menerima undangan pecotan akan menghadiri acara dengan membawa sejumlah uang sebagai bentuk sumbangan untuk diberikan kepada shahibul hajah. Sumbangan yang timbul dalam tradisi pecotan berawal dari pemberian secara sukarela, namun dari waktu ke waktu pemberian tersebut mengharapkan balasan. Sumbangan dalam tradisi pecotan ini berkembang menjadi hutang piutang antara shahibul hajah dengan tamu undangan. Dengan demikian, sumbangan ini mulai dicatat oleh masyarakat sebagai pedoman untuk mengembalikan sumbangan tersebut. Pengembalian sumbangan yang timbul dalam tradisi pecotan ini mengikuti nilai uang pada saat ingin mengembalikan sumbangan karena nilai uang sekarang berbeda dengan yang dulu. Dengan demikian, masyarakat yang mengembalikan sumbangan dapat melebihkannya dari jumlah sumbangan yang dulu diterima. Tetapi dapat pula mengembalikan 
sumbangan sesuai dengan jumlah yang dulu diterima. Namun, dalam pengembalian uang sumbangan ini tidak boleh kurang dari ketentuan masyarakat.

Pengembalian sumbangan yang ada kelebihannya ini menurut masyarakat tidak termasuk riba karena tidak ada perjanjian mengenai sumbangan ini harus diberikan lebih dari jumlah sumbangan yang dulu diterima. Tetapi sumbangan ini diberikan sesuai dengan ketentuan masyarakat dalam tradisi pecotan dan tidak boleh kurang dari ketentuan tersebut. Dengan demikian, tidak akan menjadi masalah apabila ingin memberikan sumbangan dengan melebihkannya dari jumlah sumbangan yang dulu diterima asalkan berdasarkan rasa keikhlasan. Bagi masyarakat Desa Bandaran apabila tamu undangan pecotan tidak dapat menghadiri atau memberikan amplop sesuai ketentuan masyarakat, maka dalam diri mereka akan timbul rasa malu, karena mereka lebih mempertimbangkan atau memikirkan penilaian orang lain terhadap dirinya. Sehingga menjadi keharusan bagi mereka untuk menghadiri acara Walimah al-'urs.

Dalam tradisi pecotan apabila tamu undangan kurang dalam mengembalikan uang sumbangan, maka shahibul hajah akan meminta kekurangan sumbangan tersebut setelah acara Walimah al-'urs selesai. Shahibul hajah akan menegur langsung tamu undangan setelah dua sampai tiga hari dari pelaksanaan acara Walimah al-'urs . Hal ini jarang terjadi di Desa Bandaran karena masyarakat sudah mengetahui aturan apabila diundang dengan pecotan.

Tradisi pecotan dalam Walimah al-'urs mempunyai dampak yang berpengaruh bagi kehidupan bermasyarakat baik dampak positif maupun negatif dari tradisi pecotan tersebut. Berikut dampak positif dari pelaksanaan tradisi pecotan:

Pertama, Meringankan Beban Shahibul Hajah. Tradisi pecotan dapat bertujuan baik apabila masyarakat melaksanakannya sesuai dengan ajaran Islam. Tradisi pecotan pada perayaan Walimah al-'urs terdapat sumbangan yang diberikan oleh tamu undangan kepada shahibul hajah. Sumbangan ini berguna untuk meringankan beban shahibul hajah dalam membiayai acara Walimah al-'urs . Walaupun sumbangan ini akan dikembalikan seperti layaknya hutang piutang, masyarakat tetap melaksanakan tradisi pecotan tersebut. Masyarakat menganggap sumbangan dalam tradisi pecotan ini untuk saling tolongmenolong ketika mengadakan acara Walimah al-'urs . 
Kedua, Menyambung Tali Silaturahim. Allah SWT memerintahkan untuk membina hubungan kekerabatan atau silaturahim dengan sesama muslim. Menjalin hubungan baik antar sesama akan menjadikan hidup lebih bermakna, dapat menambah teman, memanjangkan umur dan menjadikan rezeki berlimpah, sebagaimana sabda Rasulullah SAW berikut:

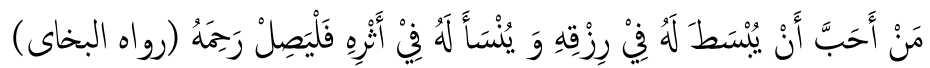

Barangsiapa yang ingin diluaskan rezekinya dan dipanjangkan umurnya, maka hendaklah ia menyambung silaturahim. (HR. Bukhari). ${ }^{20}$

Dampak negatif dari pelaksanaan tradisi pecotan, yaitu: Pertama, Ketika ingin mengembalikan sumbangan terkadang masyarakat merasa terbebankan karena dulu pernah menerima sumbangan yang jumlahnya sangat besar. Dengan demikian, di samping meringankan beban shahibul hajah sumbangan yang timbul dari tradisi pecotan ini juga dapat membebankan masyarakat dalam pengembaliannya; Kedua, Apabila tidak dapat memberikan uang sumbangan sesuai dengan ketentuan maka akan menjadi pembicaraan masyarakat lainnya sehingga akan muncul rasa malu dalam dirinya.

Seiring perkembangan zaman penggunaan tradisi ini mulai menurun. Saat ini sebagian masyarakat jarang melaksanakan tradisi pecotan yang memberikan undangan dengan sebungkus rokok melainkan hanya menggunakan kertas undangan saja. Tetapi makna dari tradisi pecotan dalam perayaan Walimah al-'urs tetap dilaksanakan, yaitu memberikan sumbangan berupa uang sebagai tambahan biaya acara Walimah al-'urs tersebut.

Sebagian masyarakat Desa Bandaran ada yang tetap mempertahankan dan melaksanakan tradisi pecotan karena masih terdapat sumbangan atau hutang yang belum dikembalikan, dengan melaksanakan tradisi pecotan dapat mengikat masyarakat untuk menghadiri acara Walimah al-'urs karena apabila hanya diundang dengan kertas undangan saja banyak yang tidak menghadiri acara tersebut, dan pelaksanaaan tradisi pecotan ini dapat menerima sumbangan uang yang jumlahnya lebih besar sebagai tambahan biaya untuk mencukupi kebutuhan dalam acara Walimah al-'urs .

${ }^{20}$ Muhammad ibn Ismail Al-Bukhari, Shahih Bukhari, Kitab ke-58: Adab, Bab 3171, Hadits Nomor 5527. 
Selain ada masyarakat yang tetap melaksanakan tradisi pecotan karena alasan-alasan di atas, ada pula masyarakat yang mulai jarang melaksanakan tradisi pecotan karena terdapat beberapa faktor yang mempengaruhinya, yaitu: pertama; faktor ekonomi menjadi salah satu alasan masyarakat Desa Bandaran mulai jarang melaksanakan tradisi pecotan. Masyarakat menganggap jika saat ini memberikan rokok sebagai simbolisasi undangan pecotan hasil sumbangannya tidak sebanding dengan pengeluaran acara pesta perkawinannya. Masyarakat sangat memperhitungkan keuntungan dan kerugiannya. Saat ini pun harga rokok semakin mahal, sehingga masyarakat berpikir ulang untuk memberikan undangan pecotan rokok sebab masyarakat ingin mendapatkan keuntungan dari sumbangan yang diberikan ketika acara walimah al-'urs.

Kedua; Perkembangan Zaman serta Kemajuan Teknologi. Seiring perkembangan zaman, adanya kemajuan di bidang teknologi dan pengetahuan menyebabkan masyarakat Desa Bandaran berubah. Masyarakat tidak lagi terikat pada tradisi yang ada karena mudah masuknya hal yang baru dalam kehidupan masyarakat pada saat ini, sehingga tradisi yang lama mulai ditinggalkan. Perkembangan zaman juga mengakibatkan pada terbatasnya waktu yang dimiliki masyarakat. Dengan demikian, masyarakat menginginkan sesuatu yang praktis dan mudah sama halnya dalam penggunaan rokok pada undangan pecotan yang saat ini jarang digunakan. Masyarakat lebih memilih menggunakan kartu undangan biasa yang tidak memerlukan banyak biaya. Padahal tradisi pecotan ini sebagai pengikat masyarakat untuk hadir dalam Walimah al-'urs, karena masyarakat dulu beranggapan jika hanya diberikan kartu undangan saja boleh tidak hadir pada acara tersebut.

Adapun faktor penyebab bergesernya tradisi pecotan ini adalah: kesatu; perubahan jumlah Penduduk. Bertambahnya jumlah penduduk ini karena ada masyarakat pendatang baru yang menetap di Desa Bandaran yang dapat menyebabkan perubahan tradisi pecotan ini. Berkurangnya penduduk karena berpindahnya masyarakat dari Desa Bandaran ke desa atau kota lainnya. Hal ini menyebabkan tradisi asli Desa Bandaran akan mulai luntur karena masyarakatnya ada yang meninggalkan tempat tersebut dan juga para sesepuh desa sudah banyak pula yang meninggal. 
Kedua; Pola pikir masyarakat menjadi berubah dan berkembang dengan menyesuaikan pada kehidupannya saat ini. Hal ini terjadi karena tingkat pendidikan di Desa Bandaran sudah tinggi sehingga pola pikir masyarakat lebih terbuka dan rasional. Masyarakat saat ini mengukur segala sesuatu dengan materi sehingga tidak lagi melaksanakan tradisi pecotan yang memerlukan banyak biaya karena harus ada rokok sebagai simbolisasi undangan.

Dari penjelasan di atas dapat disimpulkan bahwa pemberian sumbangan dalam Islam bersifat sukarela bukan sebuah kewajiban. Sumbangan pada Walimah al-'urs bertujuan untuk membantu meringankan beban shahibul hajah dalam membiayai pesta perkawinan. Namun, saat ini sumbangan yang timbul dari tradisi pecotan berkembang menjadi hutang piutang yang harus dikembalikan oleh shahibul hajah pada saat penyumbang juga ingin mengadakan Walimah al-'urs .

Meskipun saat ini tradisi pecotan jarang digunakan, namun makna dari tradisi pecotan dalam perayaan Walimah al-'urs ini tetap dilaksanakan, yaitu memberikan sumbangan berupa uang sebagai tambahan biaya acara Walimah al-'urs tersebut. Tetapi sebagian masyarakat tetap melaksanakan tradisi pecotan karena sifat dari tradisi pecotan ini berkelanjutan. Faktor yang mempengaruhi tradisi pecotan saat ini jarang dilaksanakan, yaitu karena faktor ekonomi, perkembangan zaman serta kemajuan teknologi, bertambah dan berkurangnya penduduk, dan pola pikir masyarakat yang semakin maju.

\section{Tradisi Pecotan Perspektif Ushul Fiqh}

Tradisi pecotan bagi masyarakat Desa Bandaran merupakan tradisi yang turun-temurun yang sudah ada pada zaman dahulu. Tradisi pecotan merupakan sebuah aturan yang tidak tertulis, tetapi masyarakat Desa Bandaran tetap melaksanakan tradisi tersebut ketika ada acara perkawinan. Tradisi pecotan dalam perayaan Walimah al-'urs yang berjalan di Desa Bandaran termasuk dalam kategori hutang piutang, Sumbangan dalam Walimah al-'urs awalnya bersifat sukarela dengan tujuan membantu meringankan beban shahibul hajah, namun seiring perkembangan zaman sumbangan tersebut menjadi sebuah hutang yang harus dikembalikan. 
Tradisi pecotan dalam Walimah al-urs yang diterapkan oleh masyarakat ini bertujuan untuk mendapatkan sumbangan uang yang jumlahnya lebih besar sebagai tambahan biaya dalam pesta perkawinan. Tradisi pecotan dilaksanakan oleh masyarakat Desa Bandaran karena dianggap saling membantu satu sama lain serta masyarakat mengakatan tradisi pecotan mempunyai tujuan yang baik.

Tradisi terbentuk dan bertahan karena masyarakat menganggap bahwa tradisi yang dilakukan hingga saat ini adalah sesuatu yang bermakna atau berarti, sehingga dapat mendatangkan manfaat bagi kehidupan bermasyarakat.21 Islam telah banyak mengakui adat dan tradisi yang baik yang tidak bertentangan dengan al-Qur'an dan hadits Nabi. Islam tidak menghapus tradisi yang ada, tetapi menyeleksi dan memasukkan tradisi yang baik serta meluruskan tradisi yang bertentangan dengan syariat. Kemudian tradisi yang telah dianggap baik dapat diakui dan dilestarikan dalam kehidupan masyarakat. Adapun tradisi yang buruk dan bertentangan dengan syariat harus dihapus dan ditinggalkan agar kehidupan dalam masyarakat menjadi lebih baik.22

Tradisi pecotan yang ada di Desa Bandaran dapat dikatakan sebagai 'urf, karena tradisi atau 'urf tersebut adalah sesuatu yang telah dikenal oleh masyarakat dan menjadi kebiasaan yang secara langsung dipraktikkan oleh masyarakat Desa Bandaran. Tradisi ini terbentuk secara turun-temurun dan dinilai baik ( $\left.m a^{\prime} r u f\right)$ serta dapat diterima oleh masyarakat. Hal ini sesuai dengan firman Allah dalam al-Qur'an Surah Al-A'raf ayat 199 berikut:

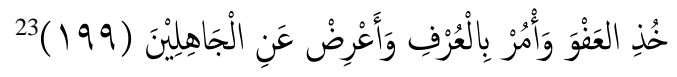

Jadilah engkau pemaaf dan suruhlah orang mengerjakan yang makruf, serta berpalinglah daripada orang-orang yang bodoh. (QS. Al-A'raf: 199). ${ }^{24}$

Ayat di atas terdapat kata 'urf (ma'ruf) yang harus dikerjakan oleh manusia. Kata 'urf ini oleh para ulama ushul fiqh dipahami sebagai sesuatu yang baik dan telah menjadi kebiasaan masyarakat. Ayat tersebut dapat dijadikan dasar untuk mengerjakan sesuatu yang dianggap baik yang telah menjadi tradisi di masyarakat

21Zenrif, Realitas Keluarga Muslim: Antara Mitos dan Doktrin Agama, 21. 22Shidiq, Ushul Figh, 102-103.

${ }^{23}$ QS. Al-A'raf (7): 199.

24Departemen Agama Republik Indonesia, Al-Qur'an dan Terjemahannya, 176. 
'Urf dapat dipakai sebagai landasan hukum apabila memenuhi syarat-syarat berikut,'Urf itu mengandung maslahat dan dapat diterima oleh akal, sehingga dapat memberikan kebaikan kepada umat dan menghindarkan umat dari kerusakan dan keburukan;'Urf itu berlaku umum dan merata di kalangan orang-orang yang berada dalam lingkungan tertentu; 'Urf yang dijadikan sandaran dalam penetapan hukum itu telah ada (berlaku) pada saat itu, bukan 'urfyang muncul kemudian. Artinya, 'urf tersebut harus ada sebelum penetapan hukum, jika urf itu datang kemudian maka tidak dapat dijadikan sebagai penetapan hukum; 'Urf itu tidak bertentangan dengan dalil syara' $^{25}$

Tradisi pecotan di Desa Bandaran saat ini mulai jarang dilaksanakan oleh sebagian masyarakatnya. Namun, berdasarkan syarat-syarat ' $u r f$ di atas tradisi pecotan dapat diterima oleh masyarakat karena dapat memberikan kebaikan dan tidak bertentangan dengan dalil syara'. Tetapi, saat ini tradisi pecotan sudah tidak berlaku umum bagi semua masyarakat Desa Bandaran. Hal ini terjadi karena sebagian masyarakat tidak lagi menggunakan undangan pecotan akan tetapi lebih memilih menggunakan kartu undangan saja. Ada pula masyarakat yang tetap mempertahankan dan melaksanakan tradisi pecotan karena sifat dari tradisi ini yang berkelanjutan.

Tradisi pecotan yang dilaksanakan oleh masyarakat Desa Bandaran mempunyai tujuan baik dengan saling tolong-menolong antar masyarakat ketika mengadakan acara perkawinan, khususnya pada saat melaksanakan Walimah al-'urs. Tradisi pecotan dalam Walimah al-'urs untuk membantu meringankan beban shahibul hajah dengan memberikan uang sumbangan sebagai tambahan biaya pesta perkawinan tersebut. Dengan demikian, tradisi pecotan mengandung nilai maslahat sehingga dapat memberikan manfaat kepada sesama. Allah SWT memerintahkan untuk saling tolong menolong dalam kebaikan, hal ini sesuai dengan firman-Nya dalam al-Qur'an Surah AlMaidah ayat 2, yaitu:

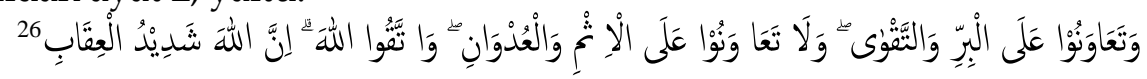

Dan tolong-menolonglah kamu dalam (mengerjakan) kebajikan dan taqwa, dan jangan tolong-menolong dalam berbuat dosa dan pelanggaran.

25Syarifuddin, Garis-Garis Besar Ushul Fiqh, 74.

26QS. Al-Maidah (5): 2. 
Dan bertakwalah kepada Allah, sesungguhnya Allah sangat berat siksa-Nya. (QS. Al-Maidah: 2).27

Berdasarkan data yang diperoleh melalui wawancara dan observasi di lapangan, tradisi pecotan dalam perayaan Walimah al-'urs di Desa Bandaran berdasarkan macam-macam 'urf dapat diklasifikasikan sebagai berikut: 'Urf dilihat dari sumbernya dibagi menjadi dua, yaitu: (1) 'Urf Qauly ialah kebiasaan yang berlaku pada kata-kata atau ucapan dalam kehidupan sehari-hari. (2) 'Urf Fi'ly ialah kebiasaan yang berlaku pada suatu perbuatan dalam kehidupan sehari-hari. ${ }^{28}$ Tradisi pecotan di Desa Bandaran berdasarkan macammacam 'urf di atas termasuk 'urffi'ly, karena tradisi pecotan merupakan suatu kebiasaan masyarakat yang berhubungan dengan perbuatan. Masyarakat Desa Bandaran melaksanakan tradisi pecotan secara langsung dengan mempraktikkan dalam kehidupan sehari-hari, khususnya ketika mengadakan Walimah al-'urs atau pesta perkawinan.

'Urf dilihat dari ruang lingkupnya dibagi menjadi dua, yaitu: (1) 'Urf 'Aam (umum) ialah kebiasaan yang telah umum berlaku di mana-mana tanpa terkecuali. (2) 'Urf Khash (khusus) ialah kebiasaan yang dilakukan oleh sekelompok orang ditempat tertentu atau pada waktu tertentu dan tidak berlaku di sembarang waktu dan tempat. ${ }^{29}$ Tradisi pecotan di Desa Bandaran berdasarkan macam-macam 'urf di atas termasuk 'urf khash (khusus), karena tradisi pecotan merupakan kebiasaan yang dilakukan oleh sekelompok masyarakat di suatu daerah tertentu. Dengan demikian, tradisi pecotan adalah kebiasaan yang telah dikenal oleh masyarakat Desa Bandaran secara turuntemurun hingga saat ini tetap dilakukan ketika ada acara pesta perkawinan. Meskipun tradisi pecotan juga dilaksanakan di daerah lain, namun dalam hal ini tradisi pecotan berlaku khusus di Desa Bandaran Kecamatan Tlanakan Kabupaten Pamekasan.

'Urf dilihat dari kualitasnya dibagi menjadi dua, yaitu: (1) 'Urf Shahih ialah kebiasaan yang dilakukan secara berulang-ulang, diterima oleh banyak orang, dan tidak bertentangan dengan syara'. (2) 'Urf Fasid ialah adat atau kebiasaan yang telah saling dikenal manusia, tetapi

\footnotetext{
27Departemen Agama Republik Indonesia, Al-Qur'an dan Terjemahannya, 106. 28Shidiq, Ushul Fiqh, 99.

29Syarifuddin, Garis-Garis Besar Ushul Fiqh, 73.
} 
kebiasaan itu bertentangan dengan dalil syara'.30 Tradisi pecotan di Desa Bandaran berdasarkan macam-macam 'urf di atas termasuk 'urf shahih, karena tradisi pecotan merupakan kebiasaan yang dilakukan masyarakat dan tidak bertentangan dengan ajaran Islam. Tradisi pecotan ini mempunyai tujuan yang baik, yaitu untuk membantu meringankan beban masyarakat ketika ingin mengadakan Walimah al'urs. Dengan demikian, tradisi pecotan mengandung unsur saling tolong menolong antara satu sama lain dan juga dapat mempererat tali silaturahmi.

\section{Kesimpulan}

Kesimpulan dalam tulisan ini, pertama bahwa Perkembangan tradisi pecotan di Desa Bandaran Kecamatan Tlanakan Kabupaten Pamekasan, berawal dari pemberian secara sukarela bukan sebuah kewajiban. Sumbangan pada Walimah al-'urs bertujuan untuk membantu meringankan beban shahibul hajah dalam membiayai pesta perkawinan. Namun, saat ini sumbangan yang timbul dari tradisi pecotan berkembang menjadi hutang piutang yang harus dikembalikan pada saat penyumbang juga ingin mengadakan Walimah al-'urs . Meskipun saat ini tradisi pecotan jarang digunakan, namun makna dari tradisi pecotan dalam perayaan Walimah al-'urs ini tetap dilaksanakan, yaitu memberikan sumbangan berupa uang sebagai tambahan biaya acara tersebut. Tetapi sebagian masyarakat tetap melaksanakan tradisi pecotan karena sifat dari tradisi pecotan ini berkelanjutan. Faktor yang mempengaruhi tradisi pecotan saat ini jarang dilaksanakan, yaitu karena faktor ekonomi, perkembangan zaman serta kemajuan teknologi, bertambah dan berkurangnya penduduk, dan pola pikir masyarakat yang semakin maju.

Pelaksanaan tradisi pecotan dalam perayaan Walimah al-'urs di Desa Bandaran telah memenuhi syarat yang menjadikan tradisi ('urf) tersebut dapat dilaksanakan dalam kehidupan masyarakat. Tradisi pecotan ini mempunyai tujuan baik dengan saling tolong-menolong antar masyarakat ketika mengadakan acara perkawinan, khususnya pada saat melaksanakan Walimah al-'urs. Tradisi pecotan perspektif 'urf dapat diklasifikasikan sebagai berikut: Pertama, dilihat dari sumbernya tradisi pecotan termasuk 'urf fi'ly (kebiasaan masyarakat yang

30Basri, Ushul Fikih 1, 125-126. 
berhubungan dengan perbuatan). Kedua, dilihat dari ruang lingkupnya tradisi pecotan juga termasuk 'urf khash (kebiasaan yang dilakukan oleh sekelompok masyarakat di suatu daerah tertentu). Ketiga, dilihat dari kualitasnya tradisi pecotan termasuk 'urf shahih (kebiasaan yang dilakukan dan diterima oleh banyak orang serta tidak bertentangan dengan ajaran Islam.

\section{Daftar Pustaka}

Agustinova, Danu Eko, Memahami Metode Tulisan Kualitatif: Teori $\mathcal{E}$ Praktik, (Yogyakarta: Calpulis, 2015).

Alamsyah, Johan, “Urgensi Konsep Al-'Ariyah, Al-Qardh, dan AlHibah di Indonesia." Yurisprudentia. Vol. 4 No. 2. Desember 2018.

Al-Bukhari, Muhammad ibn Ismail, Shahih Bukhari, (Maktabah Syamilah, $\mathrm{tt}$ )

Al-Fandi, Haryanto, Etika Bermuamalah Berdasarkan Al-Qur'an dan Sunnah, (Jakarta: Amzah, 2011).

Al-Quzwaini, Muhammad ibn Yazid ibn Majah. Sunan Ibnu Majah, (Maktabah Syamilah, $\mathrm{tt}$ )

Alwi, Bashori, "Tradisi Pecotan dalam Pandangan Ilmu Sosiologi di Paiton Probolinggo". Maqashid Jurnal Hukum Islam. Vol. 2, No. 2. 2020.

Anggito, Albi dan Johan Setiawan, Metodologi Tulisan Kualitatif, (Sukabumi: CV Jejak, 2018).

Anton, "Ungkapan Tradisional Dalam Upacara Adat Perkawinan Masyarakat Bajo Di Pulau Balu Kabupaten Munabarat". Humanika. Vol 3, No. 15. Desember 2015.

Arizza, Muhammad Rifqi, "Teori dan Praktek Akad Qardh (Hutang Piutang) dalam Syariat Islam." Vol. 9 No. 2. 2015.

Bahreisy, Hussein, Hadist Shahih Bukhari, (Surabaya: Al-Ikhlas, 1992).

Basri, Rusdaya, Ushul Fikih 1, (IAIN Parepare Nusantara Press, 2012).

Dahlan, M., Fikih Munakahat, (Yogyakarta: Deepublish, 2015).

Departemen Agama Republik Indonesia, Al-Qur'an dan Terjemahannya, ( Jakarta: Cipta Bagus Segara, 2014).

Efendi, Jonaedi dan Johnny Ibrahim, Metode Tulisan Hukum Normatif dan Empiris, (Depok: Prenadamedia Group, 2018).

Fuad, Anis dan Nugroho, Kandung Sapto, Panduan Praktis Tulisan Kualitatif, (Yogyakarta: Graha Ilmu, 2014). 
Tradisi Pecotan dalam Perayaan Walimah al-'Urs (Studi Analisis 'Urf di Desa Bandaran Kecamatan Tlanakan Kabupaten Pamekasan)

Hanbal, Ahmad ibn, Musnad Ahmad, (Maktabah Syamilah, tt).

Harun, Fiqh Muamalah, (Surakarta: Muhammadiyah University Press, 2017).

Hermawan, Iwan, Ushul Fiqh: Metode Kajian Hukum Islam, (Kuningan: Hidayatul Quran, 2019).

Jalaluddin, "Tradisi Bekhalek dalam Walimah al-'urs (Di Desa Pea Jambu Kecamatan Syari'ah dan Hukum, Singkohor Kabupaten Aceh Singkil) Menurut Madzhab Syafi'i", Skripsi, (Medan: Fakultas, Universitas Islam Negeri Sumatera Utara Medan, 2018).

Jamali, Lia Laquna, Lukman Zain dan Ahmad Faqih Hasyim, “Hikmah Walimah Al-'urs (Pesta Perkawinan) dengan Kehormatan Perempuan Perspektif Hadits." Diya Al-Afkar. Vol. 4 No. 2. Desember 2016.

Mamik, Metodologi Kualitatif, (Sidoarjo: Zifatama, 2014).

Manshur, Ali, Hukum dan Etika Pernikahan dalam Islam, (Malang: UB Press, 2017).

Moleong, Lexy J., Metodologi Tulisan Kualitatif, (Bandung: PT Remaja Rosdakarya, 2017).

Munthe, Lisna Sari, "Tradisi Nyumbang dalam Walimah al-'urs (Gesekan Sosial yang Terjadi pada Masyarakat di Desa Si Pare-Pare Tengah Kecamatan Marbau Kabupaten Labuhan Batu Utara". Skripsi, (Medan: Fakultas Syariah dan Hukum, Universitas Islam Negeri Sumatera Utara Medan, 2019.

Muyassarah, Nilai Budaya Walimah Perkawinan (Walimatul 'Urs) dalam Pemberdayaan Ekonomi Masyarakat. Vol. 10, No. 2. Desember 2016.

Qamar, Nurul, Metode Tulisan Hukum (Legal Research Methods), (Makassar: CV. Social Politic Genius (SIGn), 2017).

Rasjid, Sulaiman, Figh Islam (Hukum Figh Lengkap), (Bandung: Sinar Baru Algensindo, 2017).

Sarwat, Ahmad, Ensiklopedia Fikih Indonesia 8: Pernikahan, (Jakarta: Gramedia Pustaka Utama, 2019).

Shidiq, Sapiudin, Ushul Fiqh, (Jakarta: Kencana, 2017).

Slamet, Yulius, Pendekatan Tulisan Kualitatif, (Yogyakarta: Graha Ilmu, 2019).

Syafe'i, Rachmat, Ilmu Ushul Fiqih, (Bandung: Pustaka Setia, 2015).

Syarifuddin, Amir, Garis-Garis Besar Ushul Fiqh, (Jakarta: Kencana, 2014). 
Tho'in, Muhammad, “Larangan Riba dalam Teks dan Konteks (Studi Atas Hadits Riwayat Muslim Tentang Pelaknatan Riba)". Jurnal Ilmiah Ekonomi Islam. Vol. 02 No. 02. Juli 2016.

Tihami dan Sohari Sahrani, Fiqh Munakahat: Kajian Figh Nikah Lengkap, (Depok: Rajawali Pers, 2018).

Tim Penyusun, Panduan Praktis Penulisan Karya Ilmiah Fakultas Syariah, (Pamekasan: Fakultas Syariah IAIN Madura, 2020).

Zaki, Ayik Muhammad, "Tradisi Tonjokan Pada Walimah al-'urs di Desa Tapung Lestari Kecamatan Tapung Hilir Kabupaten Kampar Riau (Studi Komparatif Antara Hukum Islam dan Hukum Adat)". Skripsi, (Yogyakarta: Fakultas Ilmu Agama Islam, Universitas Islam Negeri Yogyakarta, 2018).

Zenrif, M. F., Realitas Keluarga Muslim: Antara Mitos dan Doktrin Agama. (Malang: UIN-Malang Press, 2008) 